\author{
Roman BÄCKER
}

Uniwersytet Mikołaja Kopernika w Toruniu

\title{
Rozumienie Rosji jako zadanie dla teorii polityki
}

\section{Wstęp}

$\mathrm{Z}$ rozumienie Rosji - jako całości lub choćby we fragmencie - jest zadaniem bardzo często przekraczającym możliwości wielu badaczy. Przykładem może być niemożność przewidzenia przez wielu sowietologów implozji jednego z dwóch największych supermocarstw pod koniec XX wieku. Niniejsza propozycja nie rości sobie pretensji do holistycznego przedstawienia wszystkich możliwych kategorii teoretycznych, dzięki którym możliwe ma być zrozumienie Rosji. To ostatnie może być tylko celem i zadaniem, ale nigdy nie jest w stanie być zakończonym zadaniem.

\section{Interpretacje językowe}

Ze względu na znaczne podobieństwo językowe między rosyjskim a polskim oraz na bardzo ścisłe i emocjonalnie zabarwione stosunki historyczne między obu narodami i ich strukturami politycznymi, konieczne jest bardzo dokładne i przezorne tłumaczenie wielu terminów. W kilku przypadkach mimo wszystko możliwe są nieporozumienia wynikające chociażby z braku ekwiwalentności terminologicznej bądź istnienia już w samej nazwie znacznego ładunku emocjonalnego. Konieczne jest zatem poczynienie odpowiednich zastrzeżeń.

Po pierwsze - w literackim języku polskim używa się jednego słowa: „rosyjski” na określenie dwóch różnych pojęć: russkij i rossijskij. W pierwszym przypadku chodzi o naród (lud) rosyjski. Drugiego terminu w języku rosyjskim używa się na określenie przynależności państwowej. Aby uniknąć nieporozumień, konieczne było dokonywanie jednolitego przekładu: „rosyjski” i często podawanie w nawiasie właściwej formy rosyjskiej.

Po drugie - odmienny problem tworzy tłumaczenie słowa sowietskij. Zarówno słowo „sowiecki” (w czasach PRL-u), jak i termin „radziecki” 
(obecnie) są obciążane wyraźną konotacją emocjonalną odpowiednio negatywną bądź pozytywną świadczącą o stosunku autora tych słów do struktury politycznej powstałej po $1917 \mathrm{r}$. W związku z tym używam tych terminów zamiennie, traktując je jedynie jako określenie nazwy własnej. Nie mam zamiaru nadawać im cech wartościujących. To samo dotyczy też takich nazw jak ZSRR (ZSRS), wzmianek o radach (sowietach) w Rosji, systemu rad (sowietów) itd.

Po trzecie - kluczowe dla historii idei politycznych słowo: władza ma w języku polskim węższe znaczenie niż rosyjskie słowo: włast'. W tym ostatnim przypadku oznacza to - jak dokładnie opisuje to Aleksander Kantor - zarówno panowanie, rządzenie, przymuszanie, wpływanie itd. Nosiciel i przedstawiciel władzy to „naczalnik”, a więc osoba reprezentująca społeczną, ogólną zasadę („naczało”), a więc uprawniona do wprowadzania porządku, ustanawiania praw, postępujący zgodnie z prawdą $(, \text {,istinoj" })^{2}$.

\section{Typy postaw wobec kultury dominującej}

Typologia postaw przedstawicieli kultury podporządkowanej, ulegającej niszczeniu wobec kultury dominującej jest jednym z najbardziej użytecznych narzędzi dla opisu rosyjskiej myśli politycznej. Jest ona bowiem znacznym rozszerzeniem i uszczegółowieniem jednego z podstawowych i najstarszych podziałów rosyjskiej sceny politycznej na okcydentalistów i antyokcydentalistów, czy używając kategorii rosyjskich na zapadnikow oraz słowianofilów, czy patriotów. Można wyróżnić cztery typy postaw w zależności od pozytywnego bądź negatywnego stosunku do kultury dominującej i do własnego narodu: natywizm, kontrakulturacja, autonegatywizm i witalizm.

Ruch natywistyczny jest to - według powszechnie akceptowanej definicji Ralpha Lintona - „każde świadome dążenie członków społeczeń-

1 Jestem zatem odmiennego zdania niż lubelski uczony Andrzej Czarnocki, który zwraca zresztą słusznie uwagę na szereg propagandowych znaczeń słowa 'radziecki' w czasach PRL-u. Zob. A. Czarnocki, Cywilizacyjno-kulturowa tożsamość Rosji, w: Federacja Rosyjska w stosunkach międzynarodowych, red. A. Czanocki, I. Topolski, Wyd. UMCS, Lublin 2006, s. 33, przyp. 25.

2 A. Kantor, Affiekt $i$ włast' w Rossii, „My i mir. Psichołogiczieskaja gazieta” 1999, nr 11, s. 13 . 
stwa do odnowy lub uwiecznienia wybranych aspektów własnej kultury"3. Kategoria ta odnosi się do tych nurtów w społeczeństwach o zniszczonej lub właśnie ulegającej zniszczeniu dawnej kulturze, które w jakikolwiek sposób dążą do odnowy swoich tradycyjnych wzorów kulturowych. Dotyczy to również tych ruchów, które zamierzają choćby na minimalnym poziomie utrwalić istnienie niezniszczonych jeszcze elementów tradycyjnej kultury, choćby dlatego, że nie zetknęły się one jeszcze z kulturą dominująca. Wyraźnie w tej definicji uwypuklony jest nie tylko aprobatywny stosunek do przeszłości, ale i pełna akceptacja własnej kultury.

$\mathrm{Na}$ inny aspekt stosunku tego typu ruchów społecznych do kultury dominującej zwraca uwagę Melville J. Herskowits. Uważa on, iż ,takie ruchy, w których ludzie podkreślają wartość rodzimych wzorów życia i dążą agresywnie, realnie czy w fantazji, do restauracji tych wzorów nawet w obliczu oczywistego i widocznego braku siły do zrzucenia władzy, która ich krępuje", można nazwać kontrakulturacyjnymi ${ }^{4}$. Ich cechą najważniejszą, wyraźnie odróżnialną od ruchów natywistycznych, jest stawianie sobie za cel negację, wyeliminowanie, wręcz wytępienie wszelkich wpływów obcej, politycznie (i cywilizacyjnie) silniejszej kultury. Składnikiem kontrakulturacji jest ogląd kultury dominującej „z tamtego brzegu”, jak to określał Aleksander Hercen. Dostrzega się istnienie tej obcej kultury, traktuje się ją jako zagrożenie, ale jej się nie rozumie. Korzysta się z jej osiągnięć (głównie technicznych), ale bez przejmowania sensu, mechanizmów i istoty funkcjonowania danej kultury.

Natywizm i kontrakulturacja są zatem postawami przeciwstawnymi do odpowiednio autonegatywizmu oraz witalizmu - postaw akceptujących obcą kulturę. Przy czym autonegatywizm jest nazwą postawy negującej własną kulturę, to postawa witalistyczna oznacza akceptację całości bądź choćby elementów kultury dominującej ${ }^{5}$. Jeśli postawy tego typu przekształcają się w bardziej rozbudowane struktury myślenia społecznego, to można mówić, jak sądzę, o osiagnięciu poziomu intelektualnego. W takim przypadku można mówić np. o intelektualnej manifestacji kontrakulturacji. Słowo: intelektualny jest tu rozumiane bardzo szeroko, jako wszelkie rozbudowane strukturalnie przejawy myślenia społecznego niekoniecznie przestrzegające zasad logiki.

\footnotetext{
3 E. Nowicka, Bunt i ucieczka, PWN, Warszawa 1972, s. 19.

4 Ibidem, s. 20.

5 Ibidem, s. 22.
} 
Postawa natywistyczna bardzo często współwystępuje w ruchach millenarystycznych, charakteryzujących się tym, że są inspirowane przez ideę zbawienia zbiorowego, ziemskiego, bliskiego, całkowitego oraz dokonanego przy pomocy czynników traktowanych jako nadprzyrodzone. Millenaryzm ponadto cechuje się posiadaniem dualistycznej wizji świata klasyfikującej wszelkie byty jako należące do świata dobra bądź zła, ludzi - na wybranych bądź potępionych, uosabiających dobro bądź uosabiających zło. Charakterystyczne jest również dla niego negowanie teraźniejszości oraz tęsknota za lepszym światem. W konsekwencji jest on archaicznym i skrajnie radykalnym przejawem społecznego protestu, który został nazwany przez Erica Hobsbawma pierwotnym rewolucjonizmem ${ }^{6}$.

W ramach millenaryzmu można wyróżnić dwa nurty: misjonizm oraz mesjanizm. Ten pierwszy uważa, że ludy mogą osiagnąć ziemskie zbawienie poprzez podporządkowanie się światu dobra. Tym samym zadaniem tego świata $\mathrm{w}$ interesie tych ludów jest ich subordynowanie. Mesjanizm zaś zawiera $\mathrm{w}$ sobie element transcendentalny ${ }^{7}$. W ten sposób można pogodzić dwa opisywane przez Ewę Nowicką przeciwstawne stanowiska teoretyczne opisujące millenaryzm: zarówno pogląd Normana Cohna oraz Yoniny Talmon, zwracających uwagę na czynniki nadprzyrodzone, jak i tezę Hobsbawma negującego istotnościowy charakter odwoływania się przez te ruchy do elementów transcendencji ${ }^{8}$.

Millenaryzm zarówno w odmianie misjonistycznej, jak i mesjanistycznej, jest tym sposobem myślenia, który na poziomie politycznym jest typowy dla grup i ludzi nie dostrzegających możliwości urzeczywistniania swoich dążeń i celów. Millenaryzm jest ucieczką od świata rzeczywistego w świat ułudy i wyobraźni, ale też zarazem jest tworzeniem alternatywnego i potencjalnego świata odmiennych znaczeń. Millenaryzm potrafi w miarę łatwo zatem przejść do wyższego poziomu - kreacji subkultur i wtedy możliwe jest tworzenie na bazie tego sposobu myślenia alternatywnych form społecznej organizacji, których przykładami mogą być neokomunitariańskie formy wspólnej egzystencji (np. komuny, czy squoty).

Definicyjnym wyróżnikiem politycznej formy intelektualnej manifestacji postawy kontrakulturacyjnej jest dążenie do wyeliminowania wszelkich wpływów kultury dominującej z własnego terytorium. Najczęściej

6 Ibidem, s. 16-17.

7 Zob. Mentalność rosyjska. Słownik, red. A. Lazari, Wyd. Śląsk, Katowice 1995, s. $51-52$.

8 Zob. E. Nowicka, op. cit., s. 17. 
tego typu nurty są określane poprzez przedrostek anty-. Tak więc można wyróżnić nurty antyglobalizacyjne, a na poziomie regionalnym rosyjski antyokcydentalizm, środkowo-europejski anty-unionizm (czy inaczej nurt anty-europejski -sceptyczny wobec Unii Europejskiej) itd.

Specyficzną formą politycznej kontrakulturacji jest religijny fundamentalizm. Jest to upolityczniona religia, która w większym stopniu przypomina ideologię polityczną niż jest renesansem religijności. Jej podstawowym elementem jest ścisłe rozróżnienie pomiędzy „nami” (a więc „wierzącymi”) a „obcymi” traktowanymi jako „niewierzący” przy czym tych ostatnich traktuje się bardzo szeroko, jako tych, którzy z nami się nie zgadzaja, nie wyznają wiary dokładnie w taki sam sposób, jak „my”. Podstawowym fundamentem światopoglądu fundamentalistów nie tylko islamskich jest pojęcie jedności odnoszonej do Jednego i Jedynego Boga, którego wola jest nakazem i drogowskazem obowiązującym każdego muzułmanina. Wierzący w Boga nie może zatem mieć jakiegokolwiek innego suwerena. Logicznie stąd wynikający wniosek o konieczności ograniczenia władzy państwowej nie oznaczał jednak pójścia w stronę np. monteskiuszowskiej koncepcji trójpodziału władzy. Według fundamentalistów, wszyscy ludzie i wszelkie struktury społeczne, w tym i polityczne muszą się podporządkować najwyższej i suwerennej władzy Boga. Tylko Bóg jest jedynym rozporządcą idei, prawa i sprawiedliwości, jedynym sędzią rozstrzygającym co jest dobre, a co złe, co moralne, a co niemoralne ${ }^{10}$.

Podstawowym zatem pytaniem jest to, kto ma prawo wiążąco interpretować wolę Boga? Np. Al-Maududi ${ }^{11}$ wprowadza pojęcie następstwa władzy Proroka. Wszyscy wyznawcy islamu, a więc społeczeństwo jako całość może być reprezentantem Proroka i Boga na świecie, oczywiście pod warunkiem pełnej realizacji zasad jedności i wspólnoty w wierze. Podobne przekonanie możemy znaleźć np. w testamencie Chomeiniego, który twierdził, że ludzie wszystkich stanów - począwszy od robotnika rolnego aż do duchownych - są odpowiedzialni za przyszłość Iranu, a przede wszystkim islamu ${ }^{12}$. Konstrukcja ta zakłada istnienie wspólnoty

9 Ibidem, s. 24-27.

10 A. Mrozek-Dumanowska, Globalizacja a idea Pax Islamica, w: Kultury pozaeuropejskie i globalizacja. Zderzenia, red. J. Zdanowski, Dom Wydawniczy Elipsa, Warszawa 2000, s. 94-95.

11 Jeden z trzech (obok Sajjid Kutny i ajatollaha Comeiniego) kontynuatorów myśli politycznej założyciela Stowarzyszenia Braci Muzułmanów Hasana al.-Banna, zmarly w 1979 roku, działający na terenie Indii i Pakistanu.

12 A. Mrozek-Dumanowska, op. cit., s. 96. 
wiernych niezależnie od jakichkolwiek podziałów społecznych. Spoiwem jednoczącym tak pojmowaną wspólnotę stają się zwykle naturalni reprezentanci wiernych danego wyznania - ich duchowni postrzegani jednak raczej jako pasterze niż przewodnicy.

Stanisław Filipowicz używa trzech różnych pojęć na oznaczenie negatywnego stosunku poszczególnych elit narodowych wobec świata zachodniego. Według niego, anty-okcydentaliści rosyjscy posługują się następującymi archetypami: separacji (świadomie akcentowanego dystansu), sprzeciwu (sporu) oraz (za Hercenem) nieustannego spoglądania na drugi brzeg, a więc poszukiwania równowagi pomiędzy inspiracjami związanymi z kulturą Wschodu i Zachodu ${ }^{13}$.

Ujęcie to jest porównywalne $\mathrm{z}$ kategoriami wywodzącymi się z antropologii kulturowej a dotyczącymi negatywnego stosunku kultury podporządkowanej do dominującej. W tym przypadku wyróżnia się natywizm oraz kontrakulturację. Natywizm to „każde świadome dążenie członków społeczeństwa do odnowy lub uwiecznienia wybranych aspektów własnej kultury" "14. Z kolei kontrakulturacja to postawa negacji, chęci wyeliminowania wszelkich wpływów obcej i silniejszej cywilizacyjnie oraz politycznie kultury $^{15}$. O ile natywizm jest porównywalny z separacją, kontrakulturacja ze sprzeciwem, to trzeci archetyp (spoglądania na drugi brzeg) mógłby być potraktowany jako osiagnięcie stanu pośredniego pomiędzy postawą akceptacji a refutacji świata zachodniego, a więc swoistego stanu zawieszenia pomiędzy traumą a erosem - tytułowymi kategoriami eseju Filipowicza.

\section{Rozumienie państwa}

Słowo państwo (gosudarstwo) wywodzi się od słów gosudar', gospodar', gospod', a więc dosłownie oznacza „pana”, zarówno pana „swoich” (czyli głowę rodu), jak i pana „obcych”, a więc niespokrewnionych. O ile

13 S. Filipowicz, Rosja i Europa - eros i trauma, w: Historia i geopolityka. Rosja na progu XXI stulecia, studia politologiczne, vol. 4, Dom Wydawniczy Elipsa, Warszawa 2000, s. 114-128.

14 E. Nowicka, Bunt i ucieczka. Zderzenie kultur i ruchy społeczne, PWN, Warszawa 1972 , s. 19.

15 Zob. R. Bäcker, Międzywojenny eurazjatyzm. Od intelektualnej kontrakulturacji do totalitaryzmu?, Wydawnictwo Ibidem, Łódź 2000. 
pierwotnie słowo gosudar' oznaczało wyłącznie gospodarza i zarazem patriarchę, najważniejszą osobę w rodzie, to później oznaczało również władcę krainy. W jednym i drugim przypadku mamy do czynienia z weberowskim panowaniem tradycyjnym i/lub opartym na zbrojnej przemocy ${ }^{16}$. Podobna jest zresztą etymologia polskiego słowa państwo, wywodzącego się od słowa: pan, a więc władca posiadający suwerenną władzę.

Pomimo odmienności etymologicznej od terminów: angielskiego (state), niemieckiego (Staat), hiszpańskiego (estado), czy francuskiego (état) wywodzących się od łacińskiego słowa oznaczającego status, a więc traktujących państwo jako bezosobowy i sformalizowany rezultat podziału ról, nie można przesądzać jeszcze o odmiennym traktowaniu państwa współcześnie. Mamy jednak do czynienia z większym poziomem uwarunkowanej kulturowo predylekcji do innego pojmowania zakresu kompetencji władczych elit rządzących państwem.

\section{Typologia nacjonalizmów}

\section{A. Wstęp}

W niniejszym tekście słowo: nacjonalizm rozumie się bardziej w sensie angielskiego słowa nationalism niż polskiego odpowiednika. Chodzi tu o wszelki sposób myślenia, dla którego najcenniejszą (lub jedną z najcenniejszych) wartości jest własny naród. Nie oznacza to zatem automatycznie traktowania innych narodów w sposób pomniejszający ich znaczenie, deprecjonujący ich wartość ${ }^{17}$.

Nacjonalizm był i jest obszarem badawczym wielokrotnie penetrowanym. Liczba publikacji jest ogromna. Do najważniejszych przeglądowych prac, ograniczając się tylko do prac analizujących XX-wieczne nacjonalizmy, należy zaliczyć m.in. prace Benedicta Andersona ${ }^{18}$, Ernesta Gellnera ${ }^{19}$,

16 Zob. Poniatije gosudarstwa w czietyriech jazykach, red. O. Charchordin, Izd. Lietnij Sad, Sankt Pietersburg-Moskwa 2002.

17 Zob. dyskusja na temat pojęcia nacjonalizm np. w: A. Miłlier, O diskursiwnoj prirodie nacionalizma, „Pro et Contra” 1997, t. 2, nr 4, s. 141-151; P. Kandel, O nacionalizmie 's cziełowieczieskom licom', ibidem, 1998, t. 3, nr 3, s. 124-135; W. Małachow, $O$ nacionalisticzieskom diskursie, ibidem, t. 4, nr 1, s. 129-132.

18 B. Anderson, Wspólnoty wyobrażone, Znak, Kraków 1997.

19 E. Gellnera, Narody $i$ nacjonalizm, PiW, Warszawa 1991. 
HansaUlricha Wehlera ${ }^{20} \mathrm{i}$ wielu innych. O wiele liczniejsze są prace poświęcone poszczególnym nacjonalizmom. Tak więc np. o nacjonalizmie rosyjskim pisali np. Michaił Agurskij ${ }^{21}$, John Dunlop ${ }^{22}$, Leonid Luks ${ }^{23}$ oraz polscy autorzy, głównie Andrzej Walicki, Andrzej de Lazari, Lucjan Suchanek i wybijający się badacze młodszego pokolenia: Jarosław Bratkiewicz, Michał Bohun, Marek Styczyński, Bożena Żejmo i inni. Wszystkie one (zarówno wymienione, jak i liczniejsze pominięte) wskazują na niesłychanie silne zróżnicowanie wszelkich, w tym i rosyjskich nacjonalizmów i jednocześnie wskazują na wiele różnorodnych tropów pozwalających na sformułowanie podstawowych kryteriów ich klasyfikacji.

Każdy rodzaj nacjonalizmu oparty na danym typie więzi narodowej jest - przy całej swojej wewnętrznej ogromnej różnorodności - w znaczącym stopniu odmienny od pozostałych prądów nacjonalistycznych w Europie. Odmienność ta wynika nie tylko z różnic religijnych, dziejów historycznych (w tym również syndromu mitów historycznych czy inaczej to ujmując - wizerunku przeszłości), kulturowego zaplecza, ale również i z odmienności językowych. O ile np. w języku niemieckim wyraźnie odróżnia się Nation i Volk, w języku angielskim nation i ethnic, to w języku rosyjskim istnieje tylko jedno słowo: народ. Słowo to oznacza zarówno lud, jak i naród. Tо ostatnie jest rozumiane zarówno jako naród polityczny (a więc ogół obywateli żyjących w danym państwie), jak i naród kulturowy (wszyscy ludzie poczuwający się do wspólnej tradycji i odczuwający wspólną więź - poczuwający się do przynależności do jednej wspólnoty narodowej). Tak więc np. nacjonalizm rosyjski ma zatem - choćby z powodów językowych - szerszy zakres znaczeniowy niż nacjonalizm niemiecki czy angielski.

\section{B. Nacjonalizmy etniczne, kulturowe i statokratyczne}

Z powyższych opisów pól znaczeniowych słowa naród (народ, nation, Nation itd.) wprost wynika podstawowy podział nacjonalizmów europejskich na: nacjonalizmy etniczne, kulturowe oraz statokratyczne.

Nacjonalizm etniczny odwołuje się do siły tradycji, pierwotnej wiary oraz moralności danego ludu. W zależności od definiowania etniczności

20 H. U. Wehler, Modernizacja nacjonalizm społeczeństwo, WP, Warszawa 2001.

21 M. Agurskij, Idieołogija Nacjonat-bolszewizma, YMCA-PRESS, Paris 1980.

22 J. B. Dunlop, The Faces of Contemporary Russian Nationalism, Princeton University Press, Princeton 1983.

23 L. Liuks, Rossija Mieżdu Zapadom i Wostokom (tłum z niem.), Moskwa 1993. 
mamy do czynienia po pierwsze z nacjonalizmem etnosu pre-narodowego - najczęściej występującym, w którym o przynależności narodowej decyduje przynależność do danego typu etnosu. Po drugie jest to nacjonalizm plemienny, a więc tendencja do traktowania jako jednego narodu (lub wspólnoty narodów) wszystkich należących do jednej pre-etnicznej wspólnoty plemiennej np. Słowian, Germanów, Galów itd. W Rosji najwybitniejszym, ale też w miarę umiarkowanym, (wyznającym jedynie wersję wschodniosłowiańską, a nie panslawistyczną) przedstawicielem tego nurtu (jak również nacjonalizmu kulturowego) jest Aleksander Sołżenicyn.

W przypadku nacjonalizmu etnicznego można też zastosować inną klasyfikację podziału ze względu na dominujące kryterium definiowania przynależności. W takim przypadku można wyróżnić nacjonalizm etniczno-lingwistyczny, etno-wyznaniowy, według pochodzenia etnicznego oraz wynikający $\mathrm{z}$ poczucia przynależności regionalnej ${ }^{24}$.

Nacjonalizm kulturowy często nazywany współczesnym jest ściśle związany z zasobem literackim, artystycznym itd. traktowanym jako przynależnym do danego typu dziedzictwa kulturowego. W tym przypadku można wyróżnić nacjonalistów zarówno na poziomie reprezentacji literackiej, ideologicznej, jak i politycznej. W tych dwóch ostatnich przypadkach kryterium podziału mogą być np. podziały ideologiczne. Liberał, socjaldemokrata bądź chadek według tegoż rozróżnienia może zatem też być nacjonalistą (kulturowym).

Nacjonalizm statokratyczny (zwany również państwowym) traktowany jest niezbyt słusznie jako tradycyjny. Należy się bowiem zgodzić, iż nie zawsze i nie wszędzie jego tradycja jest o wiele dłuższa i silniejsza niż nacjonalizmu kulturowego. Utożsamia on naród z ogółem ludności żyjącym w danym państwie. W takim przypadku można mówić w zależności od akceptowanej formy państwa o nacjonalizmie monarchicznym i republikańskim, ale też np. komunistycznym.

Podział na nacjonalizmy etniczne, kulturowe i statokratyczne jest stosowany przy opisach poszczególnych nurtów europejskiej myśli politycznej bardzo często, a najwyraźniej jest to czynione w przypadku Rosji w licznych, stojących na bardzo wysokim poziomie merytorycznym, publikacjach Andrzeja Walickiego. Nie jest to jednak jedyny możliwy podział różnorodnych nurtów europejskiej myśli nacjonalistycznej.

24 Podział ten jest transformacją klasyfikacji dokonanej przez Waltera Żelaznego (Etniczność. Ład - konflikt - sprawiedliwość, Wydawnictwo Poznańskie, Poznań 2004, s. 52 i n.). 


\section{Tradycja jako kryterium klasyfikacji nacjonalizmów}

Każde myślenie nacjonalistyczne charakteryzuje się wysokim miejscem tradycji w hierarchii akceptowanych wartości. Nie jest to jednak tradycja dowolna. Każdy nurt nacjonalizmu dobiera odpowiednie elementy tradycji w taki sposób, by można było odwołać się do pozytywnych obrazów z przeszłości („ku pokrzepieniu serc”) lub wskazania negatywnych przykładów. W przypadku nacjonalizmów europejskich widoczne jest ogromne zdyferencjonowanie i wysoki poziom segmentacji pozytywnie i negatywnie ocenianych okresów historii własnego narodu. Warto to zaobserwować na przykładzie Rosji. Zwolennicy demokracji (głównie bezpośredniej) idealizują czasy przed najazdem mongolskim. Okres panowania mongolskiego oceniany przez ogromną część rosyjskiej historiografii negatywnie (jako ,jarzmo mongolskie”) jest z kolei opisywany pozytywnie przez eurazjatów. Nacjonalizm etniczny charakteryzuje się pozytywną oceną czasów przed panowaniem Piotra Wielkiego. Nacjonalizm statokratyczny monarchiczny, ale również i w wersji imperialistycznej idealizuje Rosję XVIII- i XIX-wieczną. Komunistyczny nacjonalizm omija wszelkie negatywne określenia dotyczące czasów rządów bolszewickich.

W każdym przypadku wykorzystuje się pojedyncze elementy tradycji historycznej, opisując je w sposób wybiórczy i z dużym ładunkiem emocjonalności.

Warto w tym miejscu wspomnieć, iż stosunek do tradycji narodowej mieści się na continuum pomiędzy sakralizacją a skrajną negacją. Pomiędzy tymi dwoma biegunami możliwych postaw mieszczą się takie, jak puryfikacja, przemilczanie (celowe bądź będące rezultatem mechanizmu wypierania ze świadomości), pomijanie negatywnych bądź pozytywnych konsekwencji i w końcu relatywizowanie negatywnych cech. W im większym stopniu dany typ nacjonalizmu zbliża się do tego drugiego bieguna, im bardziej krytycznie odnosi się do przynajmniej niektórych elementów swojej tradycji, tym jest on bardziej dojrzały, w tym większym stopniu jest odporny na zewnętrzną krytykę.

\section{Nacjonalizm a religia}

Ze względu na stosunek do religii możemy wyróżnić nacjonalizmy: indyferentne, ateistyczne, pogańskie i religijne, w tym szczególnie chrześcijańskie. Jednakże ten prosty podział należy uszczegółowić w ostatnim punkcie. Eksponowanie ścisłego związku z chrześcijaństwem nie jest jednoznaczne z całkowitą wiernością teologii tej religii, czy (co nie jest całkowicie jednoznaczne) z całkowitym podporządkowaniem się wskaza- 
niom zwierzchników dominującego w danym narodzie czy etnosie Kościoła. Prócz wszelkich możliwych wariantów dystansowania się od władz oficjalnych Kościoła bądź konkretnej odmiany chrześcijańskiej teologii możliwe jest też wyznawanie innych wyznań chrześcijańskich. Prócz tego podziału możliwe jest także wyodrębnienie w ramach szeroko rozumianego chrześcijaństwa również jego dewiacji: fundamentalizmu religijnego i skrajnej postaci tegoż ostatniego: totalitarnej gnozy politycznej opartej na leksykalnym zasobie danej religii. Powyższy podział nie jest jednak wystarczający, chociażby z tego powodu, że nacjonalizmy indyferentne religijne były i są w Europie dość liczne i wewnętrznie zróżnicowane.

\section{E. Nacjonalizm a typy myślenia politycznego}

O wiele bardziej spójna klasyfikacja może zostać stworzona na podstawie podziału według kryterium typów myślenia politycznego. Tak więc można wyróżnić prócz wiary religijnej również myślenie ideologiczne, wegetatywne, trybalne i posttrybalne, fundamentalistyczne i totalitarna gnozę polityczną ${ }^{25}$.

W ramach czystych typów ideologicznego myślenia warto wyróżnić: statokratyzm, myśl imperialistyczną, nacjonalizm kulturowy, volkizm, rozmaite warianty agraryzmu (w wydaniu rosyjskim jest nim np. poczwiennictwo) itd.

Niezwykle trudne jest przedstawienie literackich epifenomenów myśli wegetatywnej. Warto jednak w tym miejscu wspomnieć o ich licznych opisach, z których do wybitnych i najbardziej znanych należą niewątpliwie teksty francuskich naturalistów, Bertolda Brechta (Matka Courage), czy w Rosji dwóch Jerofiejewów: Wienedikta oraz Wiktora ${ }^{26}$.

Z oczywistych powodów w Europie niesłychanie trudno można znaleźć klasyczne przejawy myśli trybalnej. Kilka fal modernizacji społecznej, a dokładniej: bardzo szybkich zmian społecznych, zachodzących od dru-

25 Szerzej zob. R. Bäcker, Nie-tradycyjna typologia myśli politycznej, w: Zrozumieć politykę. Główne problemy teorii polityki i współczesnej myśli politycznej, red. R. Bäcker, J. Marszałek-Kawa, J. Modrzyńska, Wyd. Adam Marszałek, Toruń 2003, s. 107-112 oraz tegoż, Typy myślenia politycznego Vilfredo Pareto a typologia kultur politycznych, w: Teoretyczne i metodologiczne problemy badań nad kultura polityczna, red. Z. Blok, Poznań 2005.

26 Należy tu przywołać nie tylko kongenialne dzieło pierwszego z nich Moskwa-Pietuszki, ale również tego drugiego Encyklopedię duszy rosyjskiej wydaną ostatnio po polsku w doskonałym przekładzie Andrzeja de Lazariego. 
giej połowy XIX wieku, poprzez fazę totalitarnej industrializacji (z jego kulminacją w latach 30-tych), aż do niezakończonej fazy włączania europejskich społeczeństw do procesów globalizacji, spowodowało, że świadomość trybalna zaniknęła. Poszczególne epigońskie formy istniejąjednak w niewielkich niszach społecznych porozrzucane na obszarze całej Europy oraz na większych obszarach Syberii, oraz terytoriów przyległych do nowych państw Azji środkowej ${ }^{27}$. Zarówno myśl wegetatywną, jak i trybalną można zaklasyfikować - posługując się pierwszym typem klasyfikacji - do pre-nacjonalizmu etnicznego.

O wiele silniej występują rozmaite formy świadomości posttrybalnej, które w swej radykalnej formie przybierają postać swoistego esprit d'corps zorganizowanych grup przestępczych, do których rekrutacja odbywa się na zasadzie przynależności terytorialnej. Swoisty ekskluzywizm terytorialny tego typu grup jest oparty na bardzo wyraźnym postrzeganiu dwóch kręgów „swojskości” - po pierwsze pochodzeniu terytorialnym oraz drugim, szerszym - opartym na swojskości etnicznej. Świadomość post-trybalna jest typowa dla wulgarnego nacjonalizmu etnicznego $\mathrm{z}$ decydującym czynnikiem przynależności regionalnej.

Myślenie fundamentalistyczne rozumiane jest tu jako swoista religia polityczna, a więc obudowanie schematów myślenia posttrybalnego (m.in. ostrego podziału na „my” i ,oni”) danym typem zasobu leksykalnego pochodzącego bądź z jakiejś ideologii, bądź religii. W takim przypadku podstawowa klasyfikacja rodzajów myślenia fundamentalistycznego będzie się opierała na podziale wg typu ideologii bądź religii stanowiącej podłoże kulturowe i leksykalne danego fundamentalizmu. Tym samym prócz religijnego nacjonalizmu fundamentalistycznego (dobrym przykładem jest, jak się wydaje, twórczość patriarchy Joanna II, a w Polsce reprezentujące relatywnie bardziej umiarkowaną wersję środowisko Radia Maryja), warto wymienić między innymi fundamentalistyczny nacjonalizm agrarystyczny, etniczno-rasistowski, ksenofobiczno-antysemicki oraz statokratyczny (zwykle w wersji mocarstwowo-imperialistycznej).

Totalitarna gnoza polityczna może przybierać rozmaite formy ${ }^{28}$. Nie tylko w przypadku krajów postkomunistycznych można mówić o różnych

27 Zob. prace naukowców z Instytutu Etnografii RAN, m.in. L. Drobiżowej.

28 Szerzej zob. m.in. R. Bäcker, Teoretyczne implikacje zmodyfikowanej definicji totalitaryzmu Juana Linza. Przyczynek do zarysu teorii totalitaryzmu, „Poznańskie Studia z Filozofii Humanistyki”, t. 6 (19): Ściezki transformacji. Ujęcia teoretyczne $i$ opisy empiryczne, Poznań 2003, s. 207-228. 
wariantach marksizmu-leninizmu (głównie w zależności od stopnia refutacji/akceptacji stalinizmu), ale również trockizmu, nazizmu, neofaszyzmu, a nawet marginalnie występującego chrześcijańskiego neonazizmu ${ }^{29}$.

\section{F. Nacjonalizm a dominująca kultura}

Ważnym kryterium podziału myśli nacjonalistycznej jest stosunek do obcych. Nie chcę tu jednak roztrząsać dobrze znanych w literaturze podziałów ze względu na poziom natężenia negatywnych stereotypów oraz emocji wobec obcych na: patriotyzm, rozumiany wąsko nacjonalizm i szowinizm. O wiele bardziej wartościowy poznawczo w przypadku nacjonalizmu jest podział ze względu na stosunek do obcej kultury, zwykle dominującej. W takim przypadku możliwe jest zastosowanie czterech podstawowych kategorii z zakresu antropologii kulturowej: witalizmu, autonegatywizmu, natywizmu oraz kontrakulturacji ${ }^{30}$. Należy je potraktować jednak w tym przypadku jako typy idealne. Tym samym realne postawy wobec kultury dominującej (szeroko rozumianego Zachodu, głównie Ameryki) rozciagają się faktycznie pomiędzy natywizmem a kontrakulturacją. Autonegatywizm z samej swojej istoty nie obejmuje swoim polem znaczeniowym jakichkolwiek nurtów nacjonalistycznych, jest bowiem ich zaprzeczeniem. Inaczej należy jednak pojmować prozelityczne traktowanie przejmowanej kultury dominującej jako swojej własnej. Tego typu postawę można potraktować jako awersową stronę rewersu autonegatywizmu. Taka postawa może zostać potraktowana jako szczególny rodzaj witalizmu. W takim przypadku przejmowanie wzorców kultury dominującej nie jest zaprzeczeniem szeroko rozumianego nacjonalizmu, ale kreowaniem swojej nowej tożsamości właśnie w oparciu o dominujący typ nacjonalizmu.

W przypadku reprezentowania kultury dominującej najczęstszym typem postawy nacjonalistycznej niechętnie co najmniej odnoszącej się do „obcych” jest witalizm polityczny. To dążenie do restauracji swojej własnej kultury odbywa się w warunkach poczucia zagrożenia ze strony przedstawicieli kultury stojącej na niższym poziomie rozwoju cywilizacji. Ta niższość cywilizacyjna, swoista i relatywna barbarzyńskość nie musi

29 Zob. np. R. Bäcker, Rosyjski faszyzm, ,Slavia Orientalis”, t. L, nr 4, R. 2001, s. 615-629, tam też obszerna literatura.

30 Zob. E. Nowicka, Bunt i ucieczka, PWN, Warszawa 1972; R. Bäcker, Międzywojenny eurazjatyzm. Od intelektualnej kontrakulturacji do totalitaryzmu?, Wydawnictwo Ibidem, Łódź 2000. 
jednak wywoływać poczucia przewagi wśród reprezentantów tego typu witalizmu politycznego. Może być wręcz odwrotnie ${ }^{31}$.

\section{G. Konkluzje}

Powyższa klasyfikacja nacjonalizmów nie jest całkowita. Możliwe jest przede wszystkim zastosowanie tradycyjnego podziału europejskiej myśli nacjonalistycznej według podstawowych, historycznie występujących nurtów. W takiej sytuacji otrzymywalibyśmy volkizm, agraryzm, nacjonalizm klasyczny, oficjalny, pangermanizm (panslawizm itd.), narodowy bolszewizm (komunizm, stalinizm), w Rosji i Azji środkowej eurazjatyzm itd. Tego typu klasyfikacja była już wielokrotnie przedstawiana i - jak się wydaje - nie wymaga ani specjalnego powtarzania, ani szczegółowego omawiania. Ma ona swój głęboki sens przy przedstawianiu historycznych form przekształceń europejskiej myśli politycznej, relacjonowania ich genezy i wzajemnych zależności. Jednakże nie oznacza to, że przedstawione przeze mnie rozmaite kryteria klasyfikacyjne myśli nacjonalistycznej nie mają znaczenia. Mogą one być bowiem znaczącą pomocą dla tworzenia siatki kategorii teoretycznych przydatnych dla opisu dowolnych nurtów europejskiej myśli zarówno globalistycznej, imperialnej, narodowej, jak i antyokcydentalistycznej, przedstawiania stopnia ich bliskości i oddalenia oraz wykrywania ewentualnych filiacji.

\section{Definicja i typologia współczesnego ekstremizmu politycznego}

\section{A. Rozważania definicyjne}

Zanim możliwe będzie przedstawienie typologii współczesnych przejawów intelektualnych i organizacyjnych ekstremizmu politycznego, konieczne jest ustalenie zasięgu granic pola tematycznego tej kategorii. Zanim zacznie się dzielić pole, najpierw trzeba wiedzieć gdzie sąjego miedze.

Najczęściej spotykaną definicją ekstremizmu politycznego jest ta, która zwraca uwagę na jego radykalny charakter oraz skłonność do używania przemocy. Tak więc czytamy: „Ekstremizm polityczny (z łacińskiego extremus - najdalszy, ostatni), wyznawanie skrajnych poglądów przez

31 Warto przypomnieć teksty Oriony Fallaci, które ukazały się po 11 IX 2001 roku. 
osoby, partie polityczne i inne organizacje oraz stosowanie radykalnych środków dla osiagnięcia zakładanych celów politycznych, ideowych czy ekonomicznych. Ekstremiści mogą zarówno reprezentować poglądy lewicowe (ekstremizm lewicowy, np. anarchizm, trockizm, maoizm), jak i prawicowe (ekstremizm prawicowy, np. nacjonalizm, faszyzm, neonazizm). Ekstremizm cechuje terror indywidualny i zbiorowy (zabójstwa, podkładanie bomb, podpalenia itp.), przemoc, zamachy wojskowe (pucze), mające na celu zastraszenie, sparaliżowanie bądź wyeliminowanie przeciwników politycznych"32.

Dla ustalenia granicy pomiędzy ekstremizmem a nie-ekstremizmem konieczne jest zatem dokładne ustalenie znaczenia dwóch następujących pojęć: skrajne poglądy oraz stosowanie radykalnych środków. Jeżeli tego się nie uczyni, to pozostaniemy na poziomie rozumienia potocznego, które jest zwykle kontekstualne zarówno czasowo, terytorialnie, jak i przede wszystkim kulturowo. Tym samym poglądy skrajne w jednym środowisku społecznym mogą być traktowane jako umiarkowane, a w zupełnie innym jako nie nadające się do zaakceptowania nawet przez członków najbardziej ekstremalnych ugrupowań. Tym samym w ujęciu kontekstualnym ugrupowania ekstremistyczne to te, które znajdują się na marginesie, to te, których poglądy i metody działania nie są akceptowane przez większość społeczności. W tym sposobie rozumienia nie ma możliwości stworzenia ogólnej definicji ekstremizmu politycznego.

Czy jednak możliwe jest stworzenie nie-kontekstualnej definicji skrajnych poglądów i radykalnych środków działania? W obu tych terminach ukryte są przecież oceny wprost odnoszące się do innych poglądów i środków działania, które są umiarkowane, generalnie akceptowane i podzielane przez większość członków danej społeczności. Jest to możliwe tylko w przypadku odniesienia zarówno poglądów, jak i środków działania do kategorii ogólnych, a nie do kontekstu.

\section{B. Ekstremizm w otoczeniu demokratycznym i niedemokratycznym}

W demokratycznych strukturach politycznych do ekstremalnych poglądów i działań politycznych należałoby zatem zaliczyć te, które nie akceptują nawet fundamentalnych wartości dla demokracji oraz społeczeństwa

32 Ekstremizm polityczny w: www.wiem.onet.pl; hasło opracowano na podstawie Stownika Encyklopedycznego Edukacja Obywatelska, Wydawnictwa Europa, Warszawa 1999. 
obywatelskiego. Inaczej mówiąc, są to te nurty i struktury, które sytuują się nie na mocy ekskluzji ze strony innych podmiotów systemu, ale ze swej istoty poza obrębem społeczeństwa obywatelskiego oraz porządku demokratycznego. Do ekstremalnych należy zaliczyć zatem te, które nie tylko opowiadają się przeciwko demokatycznemu porządkowi wartości, ale i nie wyrzekają się stosowania przemocy oraz traktują jako nadrzędne nad prawami jednostek interesy realnej bądź wyobrażonej zbiorowości ${ }^{33}$.

Inaczej jest w strukturach społecznych nie należących do porządku społeczeństwa obywatelskiego. W strukturach mono-ontologicznych, uniemożliwiających i blokujących powstawanie i istnienie innych podmiotów politycznych i opierających się na istnieniu tylko jednego, zwykle bardzo spersonifikowanego podmiotu politycznego i zarazem władczego, wszelkie inne struktury oraz poglądy muszą być traktowane jako nienależące do istniejącego porządku, a tym samym ekstremalne.

Tak więc w zależności od rodzaju struktur politycznych oraz społeczeństwa mamy do czynienia z dwojako rozumianym ekstremizmem. Podstawowy zatem podział ekstremizmów politycznych wynika z ich usytuowania społeczno-politycznego. Stąd też należy wyróżnić ekstremizm w otoczeniu demokratycznym oraz ekstremizm w środowisku niedemokratycznym. Typologia ekstremizmów politycznych musi być w każdym z tych przypadków różna.

Ekstremizm w otoczeniu demokratycznym, w warunkach społeczeństwa spluralizowanego (Popperowskiego otwartego) można dzielić ze względu na stopień natężenia refutacji istniejącego ładu społecznego. W takim przypadku będzie miał on charakter mniej lub bardziej kontrakulturacyjny. Natomiast w rozpadających się kulturach mono-ontologicznych ekstremistycznymi mogą być ruchy witalistyczne, a tym bardziej autonegatywistyczne.

\section{Konkluzje}

W otoczeniu demokratycznym z dominacją społeczeństwa obywatelskiego do nurtów ekstremistycznych można zaliczyć nurty natywistyczne i kontrakulturacyjne. W ramach nurtów natywistycznych są to często

33 To ostatnie zdanie jest kontaminacją dwóch definicji z: U. Backes, Rechstextremismus - Konzeptio und Kontroversen, w: Rechtsextreme ideologien in Geschichte und Gegenwart, Boehlau Verlag, Koeln 2003, s. 15-32, s. 32 i n.; T. Beichelt, M. Minkenberg, Rechtsradikalismus in Transformationsgesselschaften. Entstehngsbedingungen und Erklaerungensmodelle, „Ostoeuropa”, 3 (52 Jg), s. 27-262. 
struktury myślenia millenarystyczne o charakterze misjonistycznym bądź mesjanistycznym. Intelektualnymi formami kontrakulturacji są nie tylko świeckie nurty negacji kultury dominującej, ale i fundamentalizm religijny. Polityczną formą negacji świata demokratycznych wartości oraz rozpoznania tego świata jest populizm, którego strukturalnym następstwem jest autorytaryzm. Skrajną formą autorytaryzmu jest totalitaryzm.

W otoczeniu niedemokratycznym ruchami i nurtami ekstremalnymi są wszystkie wyżej wymienione (z wyjątkiem sprawującego funkcję hegemona) oraz wszelkie mniej lub bardziej rozwinięte formy i wzory demokratycznych zachowań społecznych.

W im większym stopniu dane otoczenie polityczne i społeczne zbliża się do pozycji hegemonicznej, tym mniejszy jest zakres postaw ekstremizmu politycznego. W im większym stopniu jednak przestaje być hegemonem, tym bardziej - zgodnie z logiką - powiększa się ten obszar ekstremizmu. Po przekroczeniu progu pomiędzy hegemonią a dominacją nie sposób już jednak mówić o klasycznym ekstremizmie, powstaje raczej system hybrydalny złożony z elementów dominującego systemu oraz przynajmniej części dotychczasowych ekstremistycznych nurtów i sposobów myślenia. W zależności od kształtu tej hybrydy mamy do czynienia wtedy w każdym przypadku z odmiennym treściowo i strukturalnie kształtem nurtów ekstremistycznych.

Tak więc o pozakontekstualnym charakterze ekstremistycznych nurtów i sposobów myślenia można mówić tylko w przypadku hegemonii danego (demokratycznego bądź niedemokratycznego) otoczenia społecznego. W przeciwnych przypadkach mamy do czynienia z nurtami i sposobami myślenia definiowanymi tylko poprzez kontekst usytuowanego w danym czasie konkretnego systemu.

\section{Populizm i autorytaryzm}

Czy populizm można zaklasyfikować do nurtów kontrakulturacyjnych? Niewątpliwie świadczy o tym obecne we wszystkich programach populizmu ostre przeciwstawienie między ludem, tzw. „szarym” człowiekiem, ,prostymi masami” a elitami, władcami, ludźmi „obcymi”34. Wysuwane przez te nurty proste sposoby zapewnienia dobrobytu mają bardzo często charakter misjonistyczny, a przynajmniej pozwalają na pójście

34 Szerzej zob. M. Marczewska-Rytko, Populizm. Teoria i praktyka polityczna, Wyd. UMCS, Lublin 1995. 
w kierunku takowych rozwiązań. Jednakże populizm jest jednocześnie nurtem natywistycznym, w ogromnym stopniu bowiem akcentuje potrzebę obrony kultury podporządkowanej, walkę o zachowanie jej tożsamości. Nie wydaje się jednak możliwe zakwalifikowanie wprost populizmu ani do jednego z tych nurtów, ani do obu naraz bez poczynienia znacznych uproszczeń. Populizm bowiem nie traktuje wartości kulturowych jako najważniejszych. Podstawowym celem populistycznych liderów jest zdobycie władzy. Zasób frazeologiczny oraz programowy ich wystąpień jest determinowany przez dążenie do zdobycia jak największego uznania społecznego w tych zbiorowościach, które z powodu różnych barier (zwykle kognitywnych) nie są w stanie uczestniczyć w podejmowaniu racjonalnych decyzji politycznych, w tym głównie wyborczych. Populizm jest politycznym sposobem myślenia motywującym do działania dany ruch polityczny. Po zdobyciu władzy przez ten ruch staje się populizm intelektualną podstawą dla autorytarnego systemu władzy państwowej.

Autorytaryzm w typie idealnym jest definiowany przez Juana Linza jako spełniający w całości trzy kryteria: niealternacyjna władza biurokracji bądź funkcjonariuszy resortów siłowych, powszechna apatia społeczna i specyficzna mentalność.

Mentalność autorytarna w przeważającej mierze jest determinowana przez emocje $\mathrm{e}^{35}$. Z jednej strony jest to bezkrytyczna afirmacja przywódcy o charyzmatycznych cechach, z drugiej potępienie bądź refutacja jego przeciwników politycznych. Mentalność tego typu jest kompatybilna z kulturą polityczną podporządkowania. Postawa wycofania z decydowania o sprawach politycznych jest $\mathrm{w}$ tym przypadku połączona $\mathrm{z}$ zewnętrznym podporządkowaniem się wszelkim poleceniom osób zwierzchnich. Element racjonalny przejawia się zwykle w takim sposobie wykonywania poleceń, by przynajmniej nie zaszkodzić sobie samemu.

\section{Totalitaryzm}

Pojęcie totalitaryzmu było i jest stosowane nie tylko do celów heurystycznych, ale i dla potrzeb bieżącej walki politycznej ${ }^{36}$. W rzeczywistości

35 J. Linz, Totalitaryzm i autorytaryzm, w: Władza i społeczeństwo, red. J. Szczupaczyński, Wyd. Scholar, Warszawa 1995.

36 Zob. np. obszerną pracę Marii Zmierczak, Spory o istotę faszyzmu. Dzieje i krytyka, Poznań 1988. 
totalitaryzm jest skrajną formą autorytaryzmu. Juan Linz wymienia trzy warunki, których spełnienie oznacza istnienie systemu totalitarnego:

1) monistyczny ośrodek sprawowania władzy;

2) jedna oficjalna ideologia służąca za podstawę polityki, dostarczająca sensu podstawowych znaczeń, określająca sens historii i tworząca ramy interpretacji rzeczywistości;

3) popierana, pożądana i nagradzana jest dynamiczna mobilizacja szerokich grup społeczeństwa skierowana na realizację celów wyznaczanych przez mono-partię $e^{37}$.

Pojęcie ideologii (w warunku nr 2) zatraca w tej definicji swój właściwy sens na rzecz specyficznej kategorii należącej bardziej do typu myślenia światopoglądowego (Weltanschauung), a nazywanego przez Alaina Besançona oraz Erica Voegelina gnozą polityczną. Ta ostatnia kategoria ma w przypadku totalitaryzmu o wiele większy zakres eksplanacyjny niż pojęcie ideologii ${ }^{38}$.

O ile mobilizacja mas oraz monistyczna struktura sprawowania władzy (czy też jego wizja) są prawie jednakowe dla wszystkich typów totalitarnego myślenia i organizacji, to w przypadku gnozy politycznej mamy do czynienia z wielością jej rodzajów. Typ gnozy politycznej zależy przede wszystkim od rodzaju eksploatowanego materiału semantycznego. Podstawowym kryterium podziału jest wtedy rodzaj tegoż materiału: poszczególny rodzaj ideologii (zwykle kolektywnej - a więc takiej, dla której prymarną wartościąjest jakiś typ wspólnoty) lub specyficznie rozumiana religia ${ }^{39}$.

Marksizm (ale też w jakimś stopniu agraryzm, anarchizm, syndykalizm itp.) byłby zatem podstawą semantyczną dla komunizmu. Totalitarny kosmizm, skrajny katolicki (prawosławny, szyicki itd.) fundamentalizm

37 J. Linz, Totalitaryzm i autorytaryzm, w: Władza i społeczeństwo, red. J. Szczupaczyński, Wyd. Scholar, Warszawa 1995, s. 306. Porównaj też schemat modelów autorytaryzmu i totalitaryzmu w tym samym artykule, zob. ibidem, s. 321.

38 Obszerną charakterystykę gnozy politycznej można znaleźć w wielu miejscach. Zob. przykładowo: M. Brumlik, Gnostycy. Marzenie o samozbawieniu człowieka, Wydawnictwo URAEUS, Gdynia 1999, s. 309-323; R. Bäcker, Gnoza polityczna systemu totalitarnego, w: Oblicza systemu komunistycznego w Polsce. W kręgu zła, red. P. Hübner, R. Bäcker, Wyd. DiG, Warszawa 1997, s. 5-14; Gnoza polityczna, red. J. Skoczyński, Księgarnia Akademicka, Kraków 1998. W tej ostatniej książce też obszerna dyskusja nad użytecznością tej kategorii.

39 Warto tu podać dwa przykłady: opisany przez Andrzeja Szczypiorskiego w Mszy za miasto Arras oraz fundamentalizm islamski. 
czerpałyby zatem swoje zasoby semantyczne z religii bądź ich interpretacji (także w sensie pogańskim). Natomiast faszyzm (w szerokim sensie tego słowa) może być definiowany poprzez wykorzystywanie frazeologii nacjonalistycznej, etatystycznej, konserwatywnej (bardziej z kręgu Józefa de Maistre'a i rewolucji konserwatywnej niż Edmunda Burke) itd.

Wymienione powyżej trzy typy totalitaryzmu mają charakter generalny i powinny być specyfikowane w o wiele bardziej szczegółowy sposób. Po drugie, mają one charakter typów idealnych. W rzeczywistości społecznej występują najczęściej okazy mieszane i to niezależnie od swojej samoidentyfikacji. Po trzecie, totalitaryzm funkcjonuje poza nawiasem demokracji i społeczeństwa obywatelskiego i tym samym nie stosuje się do niego parlamentarnego pochodzenia podziału na prawicę i lewicę.

Jednakże nawet zmodyfikowana definicja Linza odnosi się do systemu, który już panuje w społeczeństwie. Może ona zostać potraktowana zatem jedynie jako punkt wyjścia dla definiowania ruchów totalitarnych. Niewatpliwie w tym ostatnim przypadku kryterium nadal definiującym będzie istnienie specyficznego światopoglądu, a więc gnozy politycznej. O wiele ważniejsze od istnienia monistycznego ośrodka sprawowania władzy w danej totalitarnej organizacji nie sprawującej władzy jest wizja idealnej struktury politycznej społeczeństwa. Kierownictwo ruchu może być (i bardzo często było) podzielone i to najczęściej w wyniku bieżących i nieprzewidywalnych wydarzeń. Projekt urządzenia społeczeństwa zwykle w znaczący sposób wpływa na strategię działań oraz pozwala na przewidzenie generalnego kształtu głównych elementów organizmu społecznego kreowanego po przejęciu władzy.

Wart zmodyfikowania jest również trzeci warunek definicji Linza. Masowa mobilizacja w przypadku marginalnego ruchu jest niemożliwa. Natomiast kryterium przesądzającym o jego charakterze jest zakres wymagań stawianych uczestnikom ruchu. W takim jednak przypadku należy mówić nie o zasięgu społecznej mobilizacji, ale o wymaganiach stawianych uczestnikom ruchu i w konsekwencji o wzorcu osobowym kształtowanym w tej strukturze. Jednym z przykładów wzorca osobowego może być homo sovieticus opisany przez Aleksandra Zinowiewa, bądź wzorzec „czystego rasowo" Aryjczyka.

Reasumując - o ruchu totalitarnym (a więc znajdującym się na etapie przed zdobyciem władzy) można wtedy mówić, gdy:

1) dysponuje on wizją idealnego ustroju społecznego, w którym centralne miejsce zajmuje monistyczny ośrodek sprawowania władzy;

2) jego charakterystycznym sposobem myślenia jest gnoza polityczna oraz 
3) wzorzec osobowy promowany i propagowany w danej organizacji należy do kategorii „nowego człowieka” - połączenia sadomasochistycznego używania władzy z wypełnianiem roli mega-antroposa przy jednoczesnej redukcji funkcji życiowych do zwierzęcej wegetacji ${ }^{40}$.

Inne czynniki, takie jak: sposób funkcjonowania danej struktury organizacyjnej, wizja historii, przebóstwienie natury lub/i człowieka, bądź nie mają charakteru determinującego, bądź mogą zostać potraktowane jako jeden ze składników powyżej wymienionych.

\section{Zakończenie}

Powyższe dość skrótowe przedstawienie niektórych tłumaczeń językowych oraz kategorii teoretycznych nie wyczerpuje całości problematyki. Dla pełniejszego obrazu niewątpliwie należało np. przedstawić takie kategorie jak autorytarny władca, władza absolutna, partia władzy i wiele wiele innych.

Jednakże podstawowym celem tego tekstu nie było całościowe przedstawienie problematyki, która nigdy nie jest w stanie być wyczerpująco przedstawiona. $\mathrm{O}$ wiele ważniejsze było pokazanie pewnego sposobu myślenia wynikającego z dwóch podstawowych przesłanek. Po pierwsze konieczny jest krytyczny namysł nad zakresem semantycznym każdego słowa, każdej kategorii używanej do wyjaśniania jakiegokolwiek zjawiska społecznego. Po drugie, konieczne jest pamiętanie o ograniczeniach terytorialnych (strukturalno-świadomościowych itd.) każdego pojęcia. Jeżeli bowiem będziemy używali tego samego aparatu pojęciowego wobec wszelkich możliwych zjawisk, struktur i stanów świadomości politycznej to nie możemy liczyć na ich zrozumienie.

\section{Summary}

It is frequently beyond many researchers' abilities to understand Russia, whether as a whole or only a part. This can be exemplified by many Sovietologists' failure to forecast the implosion of one of the greatest superpowers at the end of the $20^{\text {th }}$ century. The present paper does not attempt to present a comprehensive discussion of all the

40 Szerzej: R. Bäcker, Ideat nowego człowieka w totalitarnej gnozie politycznej, w: Wychowanie a polityka. Tradycje a wspótczesność, red. W. Wojdyło, M. Strzelecki, Toruń 1997, Wyd. UMK, s. 239-245. 
possible categories that would facilitate understanding Russia. The latter can only be one's goal and task and can never be wholly completed. The fundamental purpose of this text does not involve the comprehensive presentation of a range of issues which can never be presented in an exhaustive manner. It is much more important to show a certain way of thinking based on two prerequisites. Firstly, it is necessary to critically consider the semantic range of every word and every category used to explain any social phenomenon. Secondly, it is necessary to account for the territorial limitations (related to structure and awareness) of each notion. 